\title{
Diversity of nematode assemblages along a Mediterranean deep-sea transect
}

\author{
Karline Soetaert ${ }^{1}$, Carlo Heip ${ }^{2}$, Magda Vincx ${ }^{1}$ \\ ${ }^{1}$ Marine Biology Section, Zoology Institute, State University of Gent, B-9000 Gent, Belgium \\ ${ }^{2}$ Delta Institute for Hydrobiological Research, N-4401 Yerseke, The Netherlands
}

\begin{abstract}
The diversity of nematode assemblages along a Mediterranean transect off Calvi, Corsica, Mediterranean Sea (depth range 160 to $1220 \mathrm{~m}$ ) was very high. There was no clear trend in species diversity with station depth, and diversity at the station located on the continental shelf was not markedly lower than that at the deep-sea stations. However, diversity decreased with increasing depth into the sediment. As with the macrofauna, nematode assemblages in the Mediterranean are less diverse than in the Bay of Biscay. The lower diversity in the Mediterranean is explained by a slight dominance of some species, while no species are dominant in the Bay of Biscay. Generic (betweengenus) diversity was much higher than the average species diversity within genera, indicating that the high overall species diversity was not caused by large numbers of closely related co-existing species. Since species abundances are low, mate location for amphimictically reproducing species can impose an important metabolic cost on the organism. However, there are no indications that parthenogenesis is important in deep-sea nematodes.
\end{abstract}

\section{INTRODUCTION}

The discovery in the late 1960 s of an astonishingly high diversity of small-bodied animals in the deep sea was a theoretically important and unexpected finding, and as a consequence the previously held view of an impoverished deep-sea fauna had to be abandoned (Hessler \& Sanders 1967, Sanders \& Hessler 1969, Rex 1981). Many authors have since documented high deep-sea diversity in different animal groups. Within the meiofauna, high species diversity was reported by Coull (1972) and Thistle (1983) for harpacticoids; by Tietjen (1976, 1984, 1989), Vitiello (1976), Vivier (1978), Dinet \& Vivier (1979), Rutgers van der Loeff \& Lavaleye (1986) and Jensen (1988) for nematodes; and by Gooday (1986) for foraminiferans. Nevertheless, it is very difficult to compare diversities between different areas. This is because, firstly, a wide variety of diversity indices has been used, with varying sensitivity to the more common or rare species; secondly, many indices are sensitive to the number of sample organisms (Sanders 1968, Heip et al. 1988, Soetaert \& Heip 1990).

The Mediterranean bathyal is usually considered an impoverished area, in terms of both biomass and species richness, compared to other deep-sea areas (Pérès 1985). However, these generalisations are based on the macrofauna and megafauna, since only scattered information on the meiofauna exists. In the present paper nematode diversity along a Mediterranean deep-sea transect is compared with the diversity of other deep-sea assemblages, calculated from standardized data from the literature. We examine whether nematode species diversity in the deep Mediterranean is significantly different from that in other deep-sea areas.

\section{MATERIAL AND METHODS}

The sampling area was a transect of stations at depths ranging from 160 to $1220 \mathrm{~m}$ in the Ligurian Sea (western Mediterranean), northwest of the Bay of Calvi, Corsica [see Soetaert \& Heip (1989) for coordinates and sampling methods. At each station, 2 cores $\left(10 \mathrm{~cm}^{2}\right)$ were taken from single Reineck box-core samples. Each core was horizontally subdivided into two $0.5 \mathrm{~cm}$ thick (upper layer) and four $1 \mathrm{~cm}$ thick (remaining sediment column to $5 \mathrm{~cm}$ depth) slices. All nematodes encountered in each sediment slice were identified, except for those from the shallowest station $(160 \mathrm{~m})$; for this station, in slices with more than 100 nematodes, 100 nematodes were selected at random 
and identified. In total, 391 nematodes (out of 468) were identified in the first core and 329 (out of 569) were identified in the second core. This was taken into account when constructing species lists for the entire sediment column.

Species richness was measured in 2 ways: (1) The number of species in the sample. As all nematodes were identified (except at $160 \mathrm{~m}$ depth), this equals the number of species per unit area $\left(10 \mathrm{~cm}^{2}\right)$, i.e. 'species density' (Simpson 1964). (2) The expected number of species among 100 individuals, $E\left(S_{100}\right)$, calculated following Hurlbert (1971).

Heterogeneity (sensu Peet 1974) was measured using Hill's diversity numbers (Hill 1973) of order 0, 1, 2 and $\infty$, as recommended by Heip et al. (1988). These numbers are: $N_{0}=$ number of species; $N_{1}=\exp H^{\prime \prime}$ In 2 , where $H^{\prime}=-\Sigma p_{1} \log _{2} p_{\text {i }}$ (Shannon-Wiener index, expressed in bits per individual); $N_{2}=1 / \mathrm{SI}$, where $\mathrm{SI}=$ $\sum p_{j}{ }^{2}$ (Simpon's index) and $p_{i}=$ relative abundance of the $i$-th species; $N_{\infty}=1 / p_{1}$, where $p_{1}=$ relative abundance of the most abundant species. Hill's numbers are variably sensitive to changes in the rare and common species, with the lower-order numbers giving more weight to the rarer species and the higher-order numbers giving more weight to the more common species. Thus, by using Hill's numbers of varying orders, a good estimate is obtained of the importance of rare and common species in structuring the community.

A visual representation of diversity was provided by species-abundance distributions (plotting the number or percentage of species, present with $r$ individuals, against $r$ ) and $k$-dominance curves (Lambshead et al 1983). In the latter curves, the percentage abundance of each species, ranked in decreasing order of dominance, is plotted cumulatively. Lambshead et al. (1983) noted that, whenever $2 k$-dominance curves do not intersect, all diversity indices yield a higher diversity for the sample represented by the lower curve. However, when curves do intersect, the assemblage which is taken to be the more diverse depends on the diversity index chosen.

Total diversity was compartmentalized hierarchically into a higher (i.e generic) and a lower (i.e. specific) component. Pielou (1969) showed that the ShannonWiener diversity index $H^{\prime}$ can be subdivided as $H_{\mathrm{t}}^{\prime}=$ $H_{\mathrm{g}}^{\prime}+H_{\text {wg }}^{\prime}$, where $H_{\mathrm{t}}^{\prime}=$ total diversity; $H_{\mathrm{g}}^{\prime}=$ betweengenera diversity; and $H_{\mathrm{wg}}^{\prime}=$ average within-genus diversity. Routledge (1979) generalized the hierarchical subdivision and showed that only diversity indices belonging to Hill's family can be consistently subdivided. Total diversity is calculated as the product of the group diversity (i.e. between-genera) and the (weighted) average diversity within groups (genera).

For each station along the transect and deeper than $200 \mathrm{~m}, 200$ different nematodes were drawn from the total pool by means of computer-generated pseudorandom numbers. This was repeated 10 times, and each diversity index calculated from each random draw.

To facilitate comparison of diversities observed in the transect with diversity values from other areas, we calculated $E\left(S_{100}\right)$ and Hill's diversity numbers of order $0,1,2$ and $\infty$ from species-abundance data obtained from the literature, for which the number of individuals was also standardized to 200 . Vitiello (1976), in a study of 2 Mediterranean canyons (310 to $650 \mathrm{~m}$ depth), identified exactly 200 individuals from each sample. The data of Dinet \& Vivier (1979), who analysed 185 to 217 individuals from deep stations in the Bay of Biscay (Golfe de Gascogne, 2122 to $4713 \mathrm{~m}$ depth), were used unchanged. The data provided by Vivier (1978) from a Mediterranean canyon required special treatment, as they consisted of relative abundances and were not based on 200 identified individuals. Only stations deeper than $200 \mathrm{~m}$ were considered, in order to exclude 'shelf' stations. One data set was based on 188 individuals and was used as such. Two other stations had a sample size larger than 200 individuals. These data were treated as follows: first, absolute abundances were calculated; next, cumulative abundances were calculated and stored in an array. Then 200 different pseudo-random numbers, between 1 and the total number of individuals in the sample, were generated by computer. By comparing each of these numbers with the numbers in the array, each number could be assigned to a species. This proces of subsampling was repeated 10 times, and diversity indices were calculated for each subsample. Depth of the 3 stations considered varied from 245 to $485 \mathrm{~m}$.

\section{RESULTS}

\section{Transect data}

Data concerning sediment composition and the abundance of nematodes and other meiofauna are given in Soetaert \& Heip (1989) and Soetaert et al. (in press).

Diversity values were very high (Table 1, Fig. 1): the total number of species per $10 \mathrm{~cm}^{2}$ (i.e. 'species density') varied from $101(1220 \mathrm{~m})$ to $148(280 \mathrm{~m})$; the expected number of species per 100 individuals varied from 50.5 to 62.9 , and the Shannon-Wiener diversity index per $10 \mathrm{~cm}^{2}$ varied from 5.7 to 6.5 bits ind. ${ }^{-1}$.

There was no clear trend in diversity with station depth (Fig. 1). The highest values were found at $280 \mathrm{~m}$ (all indices). Diversity at the station located on the continental shelf $(160 \mathrm{~m})$ was not lower than that at the upper continental slope. 


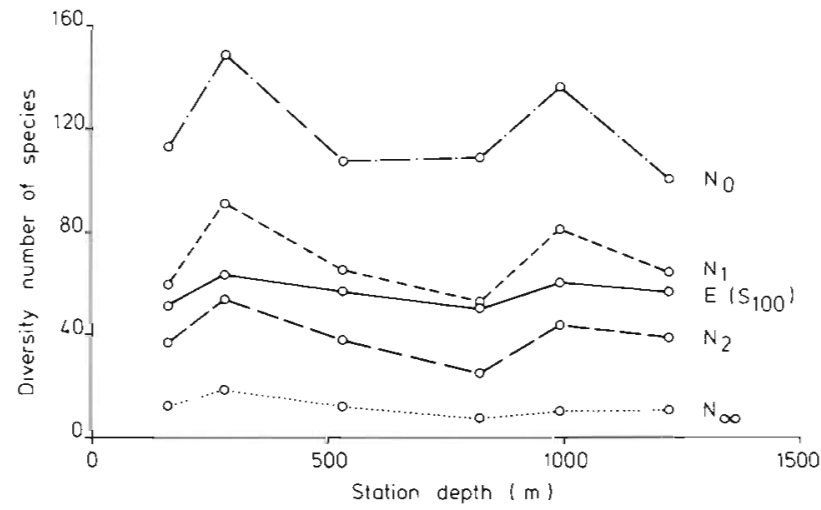

Fig. 1. Mean diversity of nematodes, calculated according to Hill's numbers $N_{0}, N_{1}, N_{2}$ and $N_{\infty}$ (Hill 1973; see 'Materials and methods') and $E\left(S_{100}\right)$ (Hurlbert 1971) per $10 \mathrm{~cm}^{2}$ for the 6 stations

Vertical distribution of diversity within the sediment is represented by means of a $k$-dominance plot in Fig. 2 . The highest diversity (lowest curve in the $k$-dominance plot) was found in the upper $1 \mathrm{~cm}$ of the sediment (280 to $1220 \mathrm{~m}$ depth). At 3 stations $(530,820$ and $1220 \mathrm{~m}$ depth), the 0 to $0.5 \mathrm{~cm}$ sediment slice exhibited higher diversity than did all other sediment horizons. At the other 3 stations (160, 280 and $990 \mathrm{~m}$ depth) it was not clear which sediment layer had the highest diversity, as the $k$-dominance curves of the 0 to $0.5 \mathrm{~cm}$ layer intersect with the $k$-dominance curve of the 0.5 to $1.0 \mathrm{~cm}$ layer, and so the various indices give contrary results.

In the stations at $160,280,530$ and $990 \mathrm{~m}$ depth, the lowest diversity (upper curve in the $k$-dominance plot) was found in the deepest sediment layer $(2$ to $5 \mathrm{~cm}$ ). At $1220 \mathrm{~m}$ this was not obvious, as the $k$-dominance
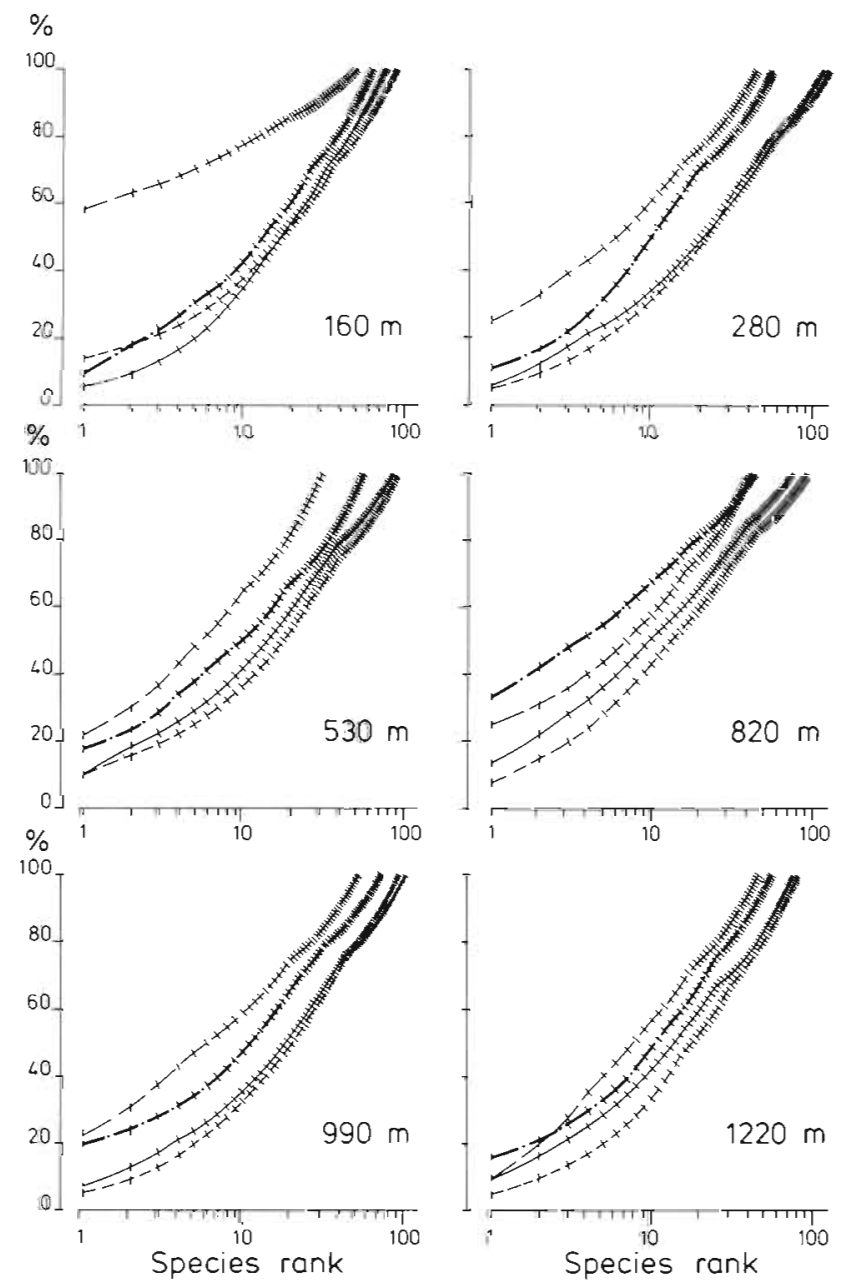

Fig. 2. $k$-dominance curves for the 6 stations, according to depth in the sediment. Hatched lines indicate depths as follows: short dashes, 0 to $0.5 \mathrm{~cm}$; continuous line, 0.5 to $1 \mathrm{~cm}$; heavy dashes/dots, 1 to $2 \mathrm{~cm}$; long dashes, 2 to $5 \mathrm{~cm}$

Table 1. Nematodes in the Mediterranean Sea. Mean density and diversity $\pm(\mathrm{SD})$ per $10 \mathrm{~cm}^{2} N=$ no. of individuals; $E\left(\mathrm{~S}_{100}\right)=$ expected no. of species per 100 individuals; $N_{0}=$ no. of species; $N_{1}=\exp \left(H^{\prime} / \ln 2\right)$, where $H^{\prime}=-\Sigma p_{i} \log _{2} p_{i i} N_{2}=1 / \mathrm{SI}$, where SI $=\Sigma p_{i}{ }^{2}$ (Simpson's index) and $p_{i}=$ relative abundance of the $i$-th species; $N_{\infty}=1 / p_{1}=$ relative abundance of the most abundant species. Hill numbers (Hill 1973) are expressed in equivalent number of species. \% Among genera: \% diversity due to amonggenera differences

\begin{tabular}{|c|c|c|c|c|c|c|c|c|}
\hline $\begin{array}{l}\text { Depth } \\
\text { (m) }\end{array}$ & $N$ & $E\left(\mathrm{~S}_{100}\right)$ & $N_{0}$ & $N_{1}$ & $N_{2}$ & $N_{\infty}$ & $H^{\prime}$ & $\begin{array}{c}\% \text { Among } \\
\text { genera }\end{array}$ \\
\hline 160 & $\begin{array}{l}518.5 \\
(71.4)\end{array}$ & $\begin{array}{c}51.3 \\
(11.7)\end{array}$ & $\begin{array}{l}113.0 \\
(18.4)\end{array}$ & $\begin{array}{c}59.1 \\
(43.1)\end{array}$ & $\begin{array}{c}36.7 \\
(39.9)\end{array}$ & $\begin{array}{c}12.3 \\
(12.8)\end{array}$ & $\begin{array}{l}5.67 \\
(1.2)\end{array}$ & $\begin{array}{l}85.5 \\
(2.6)\end{array}$ \\
\hline 280 & $\begin{array}{l}409.0 \\
(33.9)\end{array}$ & $\begin{array}{l}62.9 \\
(0.2)\end{array}$ & $\begin{array}{l}148.0 \\
(11.3)\end{array}$ & $\begin{array}{l}90.7 \\
(2.0)\end{array}$ & $\begin{array}{l}53.3 \\
(2.2)\end{array}$ & $\begin{array}{l}13.3 \\
(2.1)\end{array}$ & $\begin{array}{l}6.50 \\
(0.0)\end{array}$ & $\begin{array}{l}80.3 \\
(1.8)\end{array}$ \\
\hline 530 & $\begin{array}{c}304.0 \\
(2.8)\end{array}$ & $\begin{array}{l}56.9 \\
(0.1)\end{array}$ & $\begin{array}{l}107.0 \\
(1.4)\end{array}$ & $\begin{array}{l}65.0 \\
(5.2)\end{array}$ & $\begin{array}{c}37.6 \\
(12.3)\end{array}$ & $\begin{array}{l}11.9 \\
(4.7)\end{array}$ & $\begin{array}{l}6.02 \\
(0.1)\end{array}$ & $\begin{array}{l}80.8 \\
(3.4)\end{array}$ \\
\hline 820 & $\begin{array}{l}370.5 \\
(19.1)\end{array}$ & $\begin{array}{l}50.5 \\
(1.9)\end{array}$ & $\begin{array}{l}108.5 \\
(9.2)\end{array}$ & $\begin{array}{l}52.6 \\
(6.5)\end{array}$ & $\begin{array}{l}25.1 \\
(5.4)\end{array}$ & $\begin{array}{c}7.3 \\
(1.9)\end{array}$ & $\begin{array}{l}5.71 \\
(0.2)\end{array}$ & $\begin{array}{l}80.6 \\
(0.2)\end{array}$ \\
\hline 990 & $\begin{array}{l}404.0 \\
(65.1)\end{array}$ & $\begin{array}{l}60.3 \\
(2.5)\end{array}$ & $\begin{array}{l}135.5 \\
(17.7)\end{array}$ & $\begin{array}{c}80.6 \\
(10.0)\end{array}$ & $\begin{array}{l}43.5 \\
(3.7)\end{array}$ & $\begin{array}{l}10.1 \\
(1.0)\end{array}$ & $\begin{array}{l}6.33 \\
(0.2)\end{array}$ & $\begin{array}{l}77.9 \\
(1.0)\end{array}$ \\
\hline 1220 & $\begin{array}{l}267.5 \\
(2.1)\end{array}$ & $\begin{array}{l}56.9 \\
(1.3)\end{array}$ & $\begin{array}{l}100.5 \\
(7.8)\end{array}$ & $\begin{array}{l}64.3 \\
(1.9)\end{array}$ & $\begin{array}{l}38.7 \\
(2.5)\end{array}$ & $\begin{array}{l}10.6 \\
(2.3)\end{array}$ & $\begin{array}{l}6.00 \\
(0.0)\end{array}$ & $\begin{array}{l}81.4 \\
(1.8)\end{array}$ \\
\hline
\end{tabular}


curves for the 1-2 and 2-5 cm layers intersect. At $820 \mathrm{~m}$, the 1 to $2 \mathrm{~cm}$ layer was less diverse than the 2 to $5 \mathrm{~cm}$ layer

\section{Diversity in the Mediterranean compared with other sites}

Diversity values calculated from the other studies were also high (Table 2). The expected number of species per 100 individuals varied from 36 to $75: H^{\prime}$ varied from 4.9 to 6.8 bits ind $^{-1}$ (based on 200 individuals).

Except for $N_{0}$, the diversity values, based on data from Vivier (1978) were significantly higher (MannWhitney test) than those obtained from the data of Vitiello (1976), although both studies were undertaken in the same area (Fig. 3). As it was our intention to test whether diversity in the Mediterranean deep sea is significantly lower than at non-Mediterranean deepsea sites, we used only diversity values based on our study and on that of Vivier (1978), as these were the highest available. These values were combined for the Mediterranean sites and compared with those from the Bay of Biscay sites by means of a Mann-Whitney $U$-test.

All diversity indices from the Mediterranean had significantly lower values than those from the Bay of Biscay (Fig. $3 ; E\left(S_{100}\right): p<0.005 ; N_{0}: p=0.01 ; N_{1}: 0.001$ $<\mathrm{p}<0.005 ; N_{2}$ and $\left.N_{\infty}: \mathrm{p}=0.001\right)$. This difference was especially apparent when the more common species were emphasized (using Hill's higher-order diversity numbers), and resulted from a slight dominance of certain nematode species, i.e. species belonging to the genus Sabatieria in the Mediterranean. This genus is only present in very low numbers in the Bay of Biscay, and no other species exhibit a clear dominance in this area.

\section{Hierarchical subdivision of diversity}

Diversity calculated on the genus level was very high: 60 to 80 different genera per $20 \mathrm{~cm}^{2}$ (2 cores combined) were present, while on average only 2.2 to 2.9 species genus ${ }^{-1}$ were present. $E\left(G_{100}\right)$, the expected number of genera per 100 individuals, varied from 33 to 40 (Table 3). Of the total Shannon-Wiener diversity, 76 to $83 \%$ could be explained on the genus level; similarly, Hill's diversity numbers, calculated on the genus level, were very high compared with the average diversity within genera (Table 3 ).

In the other studies (normalized to 200 individuals), $H^{\prime}{ }_{\mathrm{g}}$ accounted for 61 to $86 \%$ of $H_{1} ; E\left(\mathrm{G}_{100}\right)$ varied from 22 to 38 , and the average number of species per genus was $\leq 3$ (Table 2).

\section{Species abundance}

Species in the transect were found primarily (40 to $47 \%$ ) in densities of 1 ind. per $20 \mathrm{~cm}^{2}$, except at the shallowest station ( $23 \%$ ) (Fig. 4). These very low values

Table 2. Diversity in the Mediterranean and the Bay of Biscay. Data presented are normalized to 200 individuals. $E\left(G_{100}\right)=$ expected no. of genera per 100 individuals; $H^{\prime}$ total: Shannon-Wiener diversity index (calculated on the species level) $\mathrm{S} / \mathrm{G}=\mathrm{no}$. of species per genus; other variables as in Table 1

\begin{tabular}{|c|c|c|c|c|}
\hline \multirow[t]{2}{*}{ Variable } & \multicolumn{4}{|c|}{ Source } \\
\hline & $\begin{array}{c}\text { Present study } \\
\text { (Mediterranean) }\end{array}$ & $\begin{array}{c}\text { Vitiello (1976) } \\
\text { (Mediterranean) }\end{array}$ & $\begin{array}{c}\text { Vivier (1978) } \\
\text { (Mediterranean) }\end{array}$ & $\begin{array}{c}\text { Dinet \& Vivier (1979) } \\
\text { (Bay of Biscay) }\end{array}$ \\
\hline$N$ & 200 & 200 & $188-200$ & $185-217$ \\
\hline \multicolumn{5}{|l|}{ Species } \\
\hline$E\left(S_{100}\right)$ & $51-64$ & $36-44$ & $45-55$ & $59-75$ \\
\hline$N_{0}$ & $80-102$ & $48-61$ & $59-83$ & $86-128$ \\
\hline$N_{1}$ & $46-75$ & $30-40$ & $40-53$ & $67-107$ \\
\hline$N_{2}$ & $25-51$ & $18-27$ & $27-37$ & $53-89$ \\
\hline$N_{*}$ & $7-14$ & $6-11$ & $9-15$ & $16-36$ \\
\hline \multicolumn{5}{|l|}{ Genera } \\
\hline$E\left(\mathrm{G}_{100}\right)$ & $33-40$ & $26-35$ & $28-38$ & $22-37$ \\
\hline$N_{0}$ & $34-45$ & $34-49$ & $35-52$ & $29-53$ \\
\hline$N_{1}$ & $19-29$ & $15-20$ & $17-30$ & $13-27$ \\
\hline$N_{2}$ & $12-20$ & $7-11$ & $10-19$ & $8-15$ \\
\hline$N_{x}$ & $5-8$ & $3-4$ & $4-7$ & $4-6$ \\
\hline$H^{\prime}$ total & $5.5-6.2$ & $4.9-5.3$ & $5.3-5.7$ & $6.1-68$ \\
\hline$\%$ Among genera & $77-82$ & $76-86$ & $76-86$ & $61-72$ \\
\hline$\%$ Within genera & $18-23$ & $1.4-24$ & $14-24$ & $28-39$ \\
\hline $\mathrm{S} / \mathrm{G}$ & $2.2-2.8$ & $1.2-1.7$ & $1.6-1.7$ & $2.2-3.0$ \\
\hline
\end{tabular}


suggest that the processing of only 2 cores per station was insufficient for estimating number of species. Data from other authors suggest comparable low densities of individuals per species, although in some cases sub- samples of only ca 100 ind. (per $10 \mathrm{~cm}^{2}$ ) were used. In the Bay of Biscay, 41 to $82 \%$ of the species were found in only 1 core, with a density of 1 ind. (Dinet \& Vivier 1979).
Fig. 3. Comparison of diversity values for stations in the Bay of Biscay and in the Mediterranean. Data from: (1) Dinet \& Vivier (1979); (2) present study; (3) Vivier (1978): (4) Vitiello (1976). Diversity values as in Fig. 1

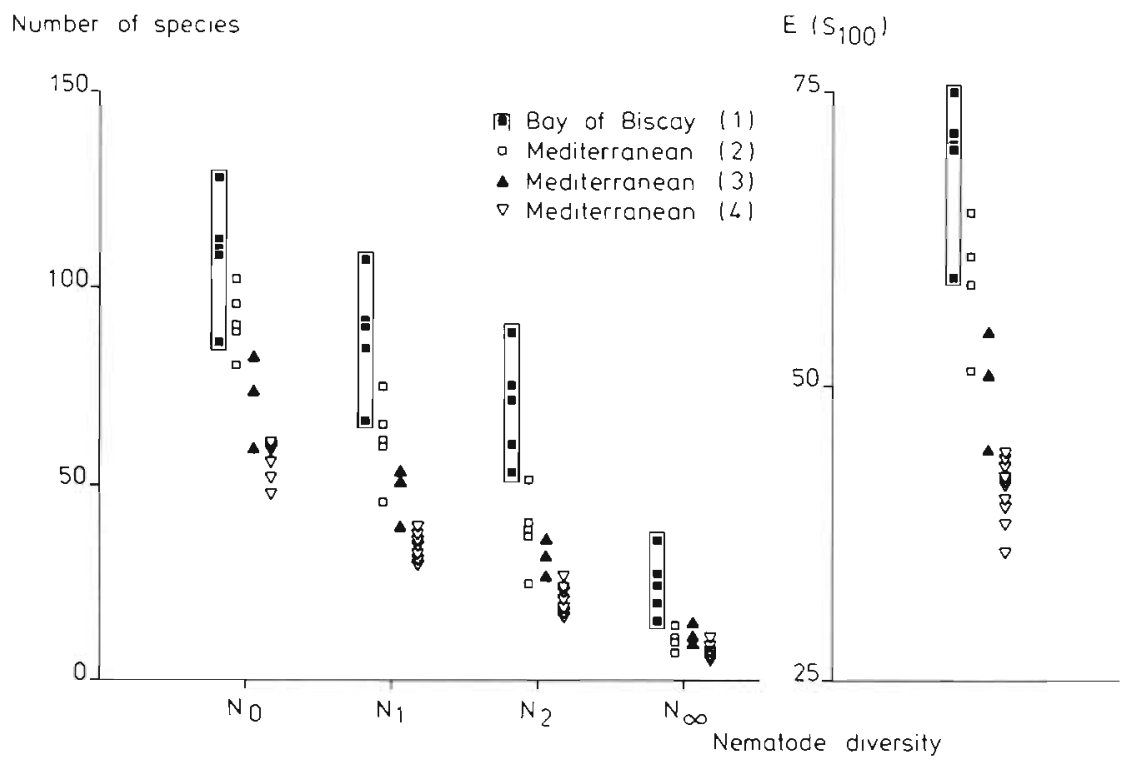

Table 3. Hierarchical subdivision of diversity. Symbols as in Tables 1 \& 2

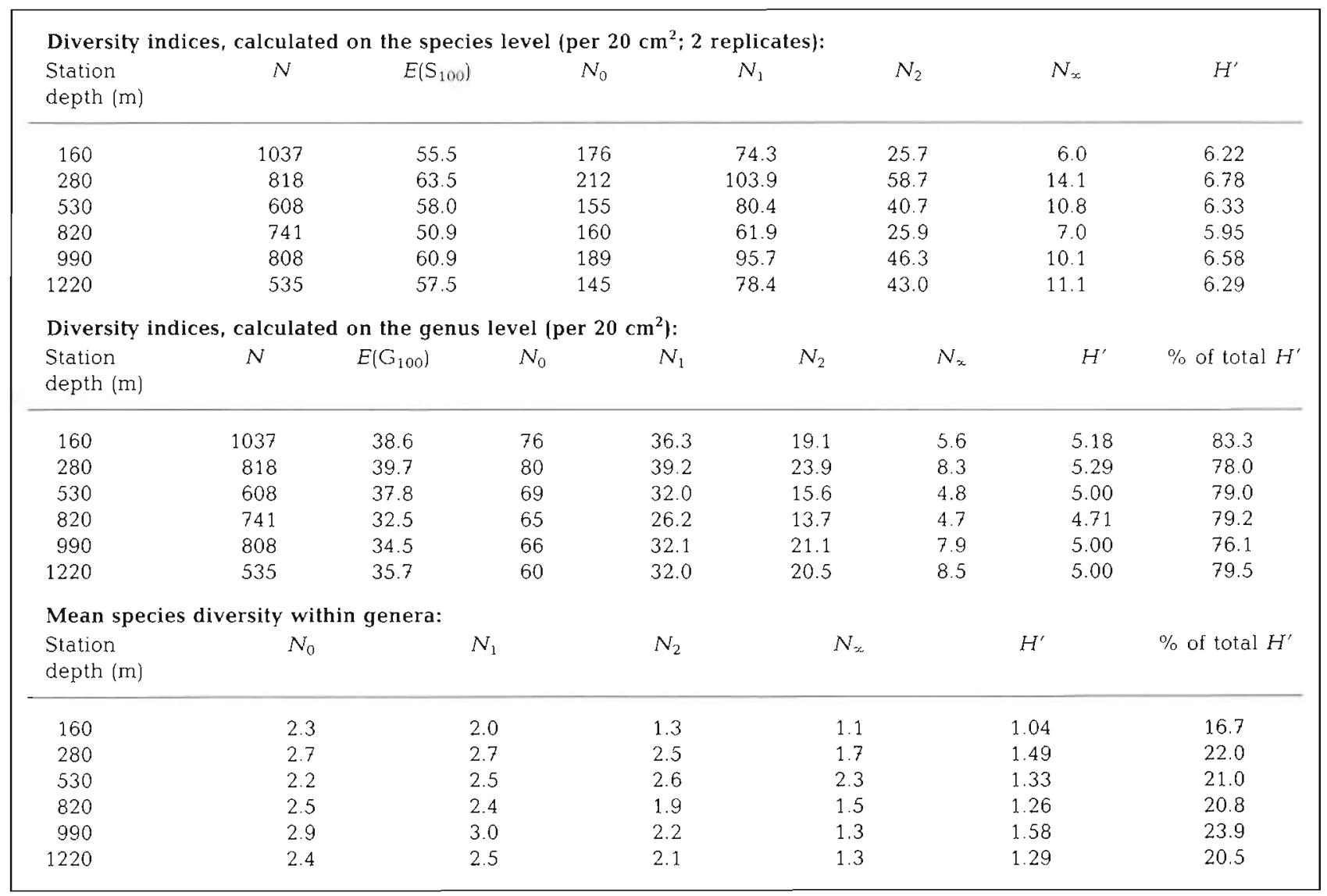



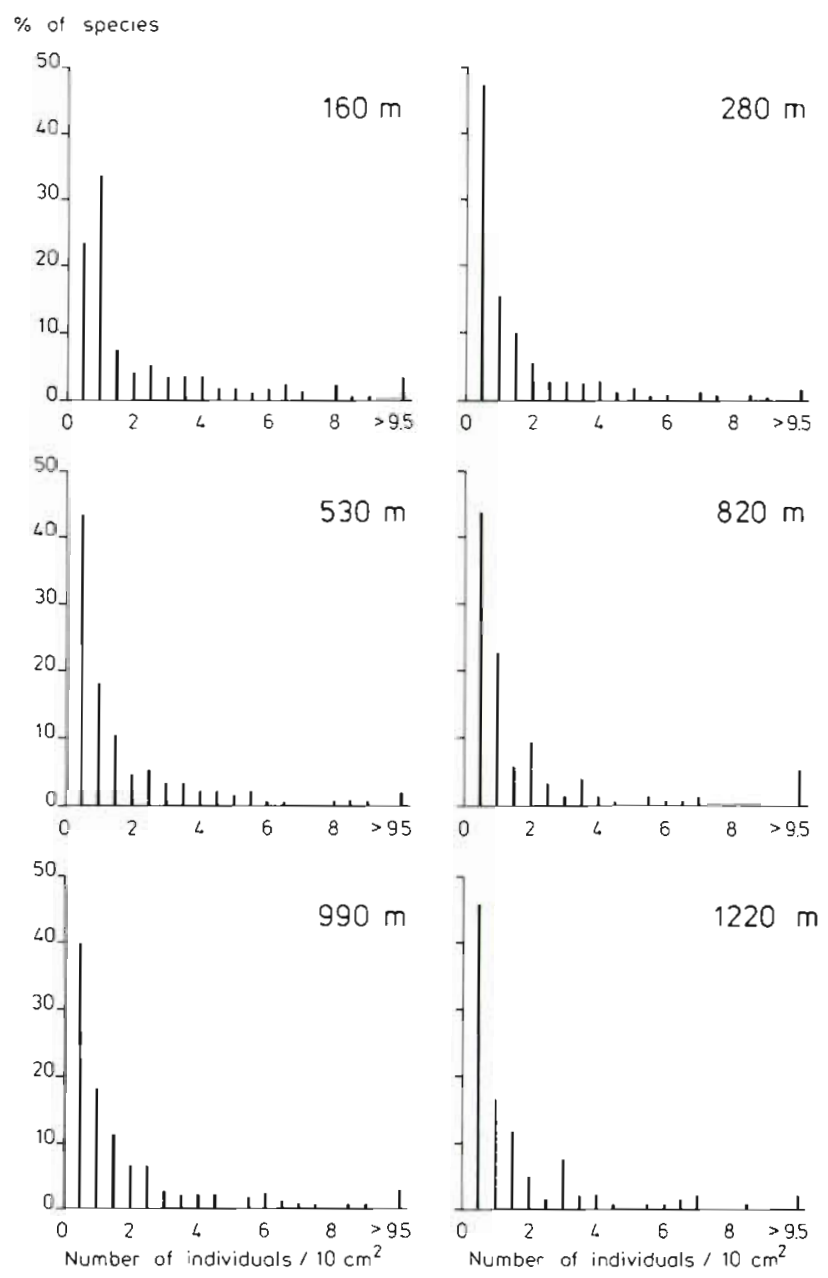

Fig. 4. Species abundance curves for the 6 stations

\section{DISCUSSION}

Nematode diversity did not exhibit any clear correlation with station depth in the studied transect; even the continental shelf station at $160 \mathrm{~m}$ depth did not have a lower diversity. Heip \& Decraemer (1974) found that nematode species diversity was positively correlated with median grain size and negatively correlated with silt-clay content of the sediment. They ascribed this to the wider range of microhabitats available for meiofauna in sandy compared to muddy sediments This may explain the high diversity at $160 \mathrm{~m}$ depth, which is the sandiest station.

The decreasing diversity with increasing depth into the sediment may have been due to more favourable conditions at superficial layers (less compact, more food), enabling more species to coexist. Soetaert \& Heip (1989) showed that smaller individuals, with their lower mobility, were preferentially found in the upper sediment layers, and attributed this to the inability of these organisms to penetrate into the deeper layers of the sediment. Similarly, Gooday (1986) showed that species richness among meiofaunal foraminiferans decreased with increasing sediment depth.

Diversity in the Mediterranean deep sea is lower than in the Atlantic, although comparison remains difficult. It should be kept in mind that replication is on the subcore and not on the box-corer level. Hence, variability in diversity indices (see Table 1) reflects spatial variability on the scale of centimeters. Our sampling design in fact does not properly replicate depth (due to logistical constraints), which limits the power of statistical analysis. Moreover, the stations studied in the Bay of Biscay were at depths ranging from 2122 to $4712 \mathrm{~m}$ while the Mediterranean stations were much shallower (245 to $1220 \mathrm{~m}$ depth). However, depth in itself probably does not explain these differences in diversity, since no relationship exists between station depth and diversity in either area. Taxonomic expertise may be another factor, since most of the diversity differences were at the species level (Table 2), where there is more opportunity for divergence between specialists. However, the literature data we used to compare the 2 areas are based on results from the same taxonomist. Lower diversity of other assemblages in the Mediterranean is usually explained by the Mediterranean's relatively young age (Messinian salinity crisis), and by the presence of a colonisation barrier formed by the Gibraltar sill and the presently existing subsurface outflow towards the Atlantic Ocean. Moreover, organisms which are able to overcome this barrier may not be able to survive, owing to the high temperature $\left(13^{\circ} \mathrm{C}\right)$ of the Mediterranean deep sea (Pérès 1985).

The Shannon-Wiener diversity index given by Rutgers van der Loeff \& Lavaleye (1986) for the NE Atlantic ranges from 5.1 to 5.7 bits ind $^{-1}$, but the numbers of individuals determined are not reported, making comparison difficult. Values reported by Tietjen (1971, $1976,1984,1989)$ and Jensen (1988) for the ShannonWiener diversity index are also difficult to compare, since neither the base of logarithm nor the number of individuals is given.

The $E\left(S_{100}\right)$ values reported for copepods in the HEBBLE site (NW Atlantic) and San Diego Trough (Thistle 1983) ranged from 43.4 to 50.8 , which is slightly lower than the values calculated for nematodes in our (Mediterranean) study. In addition, the nematode fauna at the HEBBLE site was studied by Thistle \& Sherman (1985). Some species belonging to the genera Theristus and Acantholaimus were relatively dominant, indicating that nematode diversity in this high-energy area probably is not high.

Gooday (1986) found high diversity values for meiofaunal foraminiferans from the bathyal Porcupine Seabight, which with respect to number of species (95 to 124 
per $3.46 \mathrm{~cm}^{2}$ ) were in the same range as or even higher than nematode diversities reported in the present study. About half of the species were represented by single specimens (per $3.46 \mathrm{~cm}^{2}$ ), and 11 to $19 \%$ by 2 specimens. Shannon-Wiener diversity indices are given but were calculated for a variable number of individuals, and the base of the logarithm is not reported.

In all deep-sea studies considered here, the diversity between genera was much higher than the average diversity within genera. The high overall diversity therefore does not imply that many closely related species coexist in the deep sea.

The very low species density has some important implications for individual organisms. If organisms are randomly distributed with average density $D$, the expected (or meanj distance between nearest neighbours $\left(r_{E}\right)$ can be calculated as:

$$
r_{\mathrm{E}}=1 /(2 \sqrt{\mathrm{D}})
$$

(Clark \& Evans 1954). Thus, an abundance of 1 ind. per $20 \mathrm{~cm}^{2}$ implies that the expected distance to the nearest conspecific is $2.2 \mathrm{~cm}$. Wilson \& Hessler (1987) noted that the average species population density of macrofauna in an abyssal area in the Equatorial Pacific was 0.58 ind $\mathrm{m}^{-2}$. They subsequently calculated that, on average, a $1 \mathrm{~mm}$ long individual would be separated from another one by ca 1318 body lengths (this calculation probably implies a regular distribution pattern, in which every individual has 4 nearest neighbors; the distance to one of these neighbors is then $1 / \sqrt{D}$, or $1.31 \mathrm{~m})$. When applying the formula of Clark \& Evans (1954), the expected distance to nearest neighbours becomes $0.675 \mathrm{~m}$, or ca 657 body lengths, which is still an impressive figure.

For organisms ca $0.5 \mathrm{~mm}$ long (Soetaert \& Heip 1989), the same calculation yields an inter-individual distance of about 44 times body length. For amphimictically reproducing organisms, it is necessary that 2 individuals of opposite sex encounter each other. If we assume that approximately half of all individuals are adults and that the sex ratio is $1: 1$, then only 1 out of 4 encountered conspecifics is available for mating. Some nematode species are known to produce pheromones (Samoiloff et al. 1974, Green 1980, Jensen 1982); however, certain factors reduce the probability of chemical attraction within the sediment over large distances: (1) the impermeability of deep-sea clay and hence low diffusion rate of chemical substances, and (2) the presence of a multitude of species in a relatively small area, with each species having its own attractant. It therefore seems unlikely that individuals can detect one another at such great distances (i.e. $>44$ body lengths), implying that randomness must play an important role in mate detection. This further increases the distance organisms must travel to encounter their mates. Thus, mate detection would impose an important metabolic cost on the organisms if their distribution were random, and so random spatial distribution of species seems unlikely, since conservation of energy is considered to be the major structuring force in the deep sea. It has been established, for example, that deep-sea harpacticoids are non-randomly distributed on a scale of centimetres (Eckman \& Thistle 1988).

On the other hand, it is not known whether all or even most species reproduce amphimictically, and parthenogenesis is common among opportunistic shallow-water species (see Heip et al. 1985 for review). Opportunistic deep-sea species have been reported by Bovée (1987) from a canyon in the Mediterranean, and Gooday (1986) observed that certain meiofaunal foraminiferans reacted opportunistically to freshly deposited detritus. In the present study, the overall sex ratio varied between 33 and $44 \%$ males in the adult population, displaying no clear trend with depth, and as an average this is far too high to ascribe an important role to parthenogenesis.

Acknowledgements. This project was funded through grant 2.9007.82, 'Ecology and Systematics of Marine Organisms' (C. Heip, principal investigator), of the Belgian National Fund for Collective Fundamental Research. K.S. acknowledges a grant as 'aspirant' of the Belgian National Fund for Scientific Research. We thank W. Gyselinck for making slides, and D. Van Gansbeke and the crew of the RV 'Dubuisson' (Station de Recherches Sous-Marins et Océanographiques, Calvi, Corsica) for their help in sampling. Contribution no. 536 of the Delta Institute for Hydrobiological Research.

\section{LITERATURE CITED}

Bovèe, F de (1987). Dynamique des nématodes profonds. Structures quantitatives et dimensionelles. Coll. Intern. Océanol. Perpignan, CIESM: 69

Clark, P. J., Evans, F. C. (1954). Distance to nearest neighbor as a measure of spatial relationships in populations. Ecology 35: 445-453

Coull, B. C. (1972). Species diversity and faunal affinities of meiobenthic Copepoda in the deep sea. Mar. Biol. 14: $48-51$

Dinet, A., Vivier, M. H. (1979). Le méiobenthos abyssal du Golfe de Gascogne. II. Les peuplements de nématodes et leur diversité spécifique. Cah. Biol. mar. 20: 109-123

Eckman, J. E., Thistle, D. (1988). Small-scale spatial pattern in meiobenthos in the San Diego Trough. Deep Sea Res. 35 (9): $1565-1578$

Gooday, A. J. (1986). Meiofaunal foraminiferans from the bathyal Porcupine Seabight (northeast Atlantic): size structure, standing stock, taxonomic composition, species diversity and vertical distribution in the sediment. Deep Sea Res. 33 (10): 1345-1373

Green, C. D. (1980). Nematode sex attractants. Helminth. Abstr. B 49: 81-93

Heip, C., Decraemer, W. (1974). The diversity of nematode communities in the southern North Sea. J. mar. biol. Ass. U.K. 54: 251-255 
Heip, C., Herman, P. M. J., Soetaert, K. (1988). Data processing, evaluation and analysis. In: Higgins, R. H., Thiel, H. (eds.) Introduction to the study of meiofauna. Smithsonian Institution Press, Washington, D.C., p. 197-231

Heip, C., Vincx, M. Vranken, G. (1985). The ecology of marine nematodes. Oceanogr mar. Biol. A. Rev. 23: 399-489

Hessler, R. R., Sanders, H. L. (1967). Faunal diversity in the deep sea. Deep Sea Res. 14: 65-78

Hill, M. O. (1973). Diversity and evenness: a unifying notation and its consequences. Ecology 54: 427-432

Hurlbert, S. H. (1971). The nonconcept of species diversity: a critique and alternative parameters. Ecology 52: 577-586

Jensen, P. (1982). Reproductive behaviour of the free-living marine nematode Chromadorita tenuis. Mar. Ecol. Prog. Ser. 10: 89-95

Jensen, P. (1988). Nematode assemblages in the deep-sea benthos of the Norwegian Sea. Deep Sea Res. 35: $1173-1184$

Lambshead, P. J. D., Platt, H. M., Shaw, K. M. (1983). The detection of differences among assemblages of marine benthic species based on an assessment of dominance and diversity. J. nat. Hist. 17: 859-874

Peet, R. K. (1974). The measurement of species diversity. A Rev. Ecol. Syst. 5: 285-397

Pérès, J. M. (1985). History of the Mediterrranean biota and the colonization of the depths. In. Margalef, R. (ed.) Western Mediterranean. Pergamon Press, Oxford, p. $198-232$

Pielou, E. C. (1969). An introduction to mathematical ecology. J. Wiley \& Sons, New York

Rex, M. A. (1981). Community structure in the deep-sea benthos. A. Rev. Ecol. Syst. 12: 331-353

Routledge, R. D. (1979). Diversity indices: which ones are admissible? J. theor. Biol. 76: 503-515

Rutgers van der Loeff, M. M., Lavaleye, M. S. S. (1986). Sediments, fauna and the dispersal of radionuclides at the N.E. Atlantic dumpsite for low-level radioactive waste. Report of the Dutch DORA program. Netherlands Institute for Sea Research, Texel

Samoiloff, M. R., Balakanich, S., Petrovich, M. (1974). Evidence for the two-state model of nematode behaviour Nature, Lond. 247. 73

This article was submitted to the editor
Sanders, H. L. (1968). Marine benthic diversity: a comparative study. Am. Nat. 102: 243-282

Sanders, H. L., Hessler, R. R. (1969). Ecology of the deep-sea benthos. Science 163: 1419-1424

Simpson. G. G. (1964). Species density of North American recent mammals. Syst. Zool. 13: 57-76

Soetaert, K., Heip, C. (1989). The size structure of nematode assemblages along a Mediterranean deep-sea transect. Deep Sea Res. 36: 93-102

Soetaert, K., Heip, C. (1990). Sample-size dependence of diversity indices and the determination of sufficient sample size in a high-diversity deep-sea environment. Mar. Ecol. Prog. Ser. 59: 305-307

Soetaert, K., Heip, C., Vincx, M. (in press). The meiobenthos along a Mediterranean deep-sea transect off Calvi (Corsica) and in an adjacent canyon. P.S.Z.N.I. Mar. Ecol.

Thistle, D. (1983). The stability-time hypothesis as a predictor of diversity in deep-sea soft-bottom communities: a test. Deep Sea Res. 30(3A): 267-277

Thistle, D., Sherman, K. M. (1985). The nematode fauna of a deep-sea site exposed to strong near-bottom currents. Deep Sea Res. 32: 1077-1088

Tietjen, J. H. (1971). Ecology and distribution of deep-sea meiobenthos off North Carolina. Deep Sea Res. 18: 941-957

Tietjen, J. H. (1976). Distribution and species diversity of deep-sea nematodes off North Carolina. Deep Sea Res. 23: $755-768$

Tietjen, J. H. (1984). Distribution and species diversity of deep-sea nematodes in the Venezuela Basin. Deep Sea Res. 31. 119-131

Tietjen, J. H. (1989). Ecology of deep-sea nematodes from the Puerto Rico Trench area and Hatteras Abyssal Plain. Deep Sea Res. 36: 1579-1594

Vitiello, P. (1976). Peuplements de nématodes marins des fonds envasés de Provence. II. Fonds détritiques envasés et vases bathyales. Annls Inst. océanogr., Monaco 52 (2) 283-311

Vivier, M. H. (1978). Influence d'un déversement industriel profond sur la nématofaune (canyon de Cassidaigne, Méditerranée). Téthys 8 (4): 307-321

Wilson, G. D., Hessler, R. H. (1987). Speciation in the deep sea. A. Rev. Ecol. Syst. 18: 185-207

Manuscript first received: September 18, 1989

Revised version accepted: June 7,1991 